\title{
THE ROLE OF THE REFLEXIVE SELF IN MAILER'S PROTESTS
}

\section{JON DEAN}

Department of Psychology, Sociology \& Politics, Sheffield Hallam University

\begin{abstract}
In The Armies of the Night (1968) and Miami and the Siege of Chicago (1968/2008) Norman Mailer details the exploits of the anti-Vietnam war protestors and his role in the protests. With an ethnographer's eye for detail and a novelist's eye for imagery, he constructs a picture of youthful fear and exuberance, a totalitarian reaction to protest, and documents an America which he realises is slowing eating itself. In these nonfiction novels, he places himself at the centre of events, interpreting the data through his own frazzled, drink-fuelled, mischievous self. This article utilises Pierre Bourdieu's methodological framework of reflexive sociology to both critically analyse Mailer as an ethnographer and qualitative researcher and ask whether inquiry into social protest can be adequately conducted through the autobiographical gaze of a novelist. It is argued that by using such literary resources and techniques, we can, in the spirit of C. Wright Mills, move to a more public sociology where literary techniques are valued, rather than dismissed as unscientific.
\end{abstract}

\section{Keywords}

Bourdieu, literature, Norman Mailer, qualitative methods, reflexive research

\section{Corresponding author:}

Jon Dean, Email: j.dean@shu.ac.uk.

The author wishes to thank Bob Jeffery and the two anonymous reviewers for the comprehensive and helpful comments they provided in the development of this article. 
Mailer may have been a misanthropic bastard, but Holy Toledo, the man could write. He was a chronicler, a first-rate observer, and a commentator the likes of which we may never see again. In his coverage of the Miami and Chicago conventions, he kowtowed to no one.

'Maureen', June 1st 2009

Paying attention is precisely what the literary journalist in his nonfiction writings [sic], and what Miami and the Siege of Chicago...shows is that for all his self-obsession, Mailer was no mere narcissistic punk considering the world his realm and its inhabitants his subjects.

'Ted Burke', March 27th 2009

\section{[T] his book. [Miami and the Siege of Chicago] is lumpy and tangled and has mailer's [sic] heart and testicles all over it.}

'brian', September 24th 2008

$\mathrm{T}^{\mathrm{s}}$

he above quotations from Goodreads.com ${ }^{1}$, the book review and information website, give an insight into the world of Norman Mailer, and what he attempted to achieve in his accounts of the October 1967 march on the Pentagon attended by 400,000 protestors (Akatiff, 1974, p. 30), and the US Presidential nominating conventions of 1968. These books, The Armies of the Night (1968) and Miami and the Siege of Chicago (1968/2008) respectively ${ }^{2}$, detail the enormous social and political upheaval in the US in the late-1960s, brought about by intensifying anger and revulsion at America's military role in Southeast Asia, widely decried as imperialist and inhumane. Mailer's reporting of these events was to be a highpoint of a long and varied career, earning him the Pulitzer Prize and National Book Award for Armies, as he sought to establish himself at the centre of both the burgeoning New Journalism movement, and satisfy his intellectual and egotistical craving for appreciation (H. Mills, 1985).

This article seeks to argue that there is a substantial amount that social science research into social protest can learn from Mailer's style and approach in these two books -and that producing a social science 'with heart and testicles all over it' is not a challenge to shy away from. Specifically, I argue that Mailer's process in these texts is actually a prescient and accessible application of Pierre Bourdieu's notion of 'reflexive sociology' (Bourdieu, 1990, 1999, 2003; Bourdieu \& Wacquant, 1992), a methodological approach where researcher subjectivities and positionality are laid bare, and are used as explicit windows through which reading publics experience the generated data. If an ethnography is to know that the study of human relations is 'necessarily an embedded one [where] to pretend otherwise obscures more than it illuminates' (Kahn, 2011, p. 201-2), Mailer presents an ethnographic study in which he honestly presents his own predilections, faults, and internal contradictions and confusions, in order to aid understanding (both his own and the general public's) of the torrent of crises engulfing American institutions in the late 1960s. Further, this article considers the language and literary notions Mailer applies in his analyses, adding literary perspective to current sociological debates about egalitarian approaches to the communication of (social) science.

Qualitative studies of protest, particularly those which utilise participant observation

1 These reviews and more can be found at http://www.goodreads.com/book/show/131788.Miami_and_the_Siege_ of_Chicago, retrieved March 23rd 2013. Utilising online comments for research purposes is covered by Van Zoonen (2005, pp. 123-42).

2 To benefit the reader, these texts shall henceforth be referred to as Armies and Miami and Chicago. 
or ethnographic methods are unavoidably grounded in visceral experience. The emotional and physiological experiences of the researcher, from anger, to adrenaline, to fear, to the sound of blood rushing through the ears, are all part of the subjective state of data collection. People make sense of their world through the stories they tell about them (Sikes \& Gale, 2006; McAdams, 2008; Polletta, 2008), and the stories which Norman Mailer tells about the anti-Vietnam war protests, and the methods and literary techniques he uses to tell these stories, are a more than creditable way to understand the processes behind social action and political protest. The stories told in and about social movements have power, a power which comes not necessarily from the clarity of their moral message but the often time ability to generate 'narrative fidelity' (Polletta, 2009), reinforcing a message of movement coherence and resonance that is allied with popular narratives. Since Jasper's (1998, p. 397) assertion that 'emotions have disappeared from models of protest', there have been a growing number of writers who have tackled the role of emotional connection in their study and understanding of social protest (Woods, Anderson, Guilbert \& Watkin, 2012; Van Stekelenburg \& Klandermans, 2013), set within the cultural turn in the social sciences. Emotions have been seen as a reaction against the conceptualisation of participants as rational actors (Jasper, 1998; Goodwin, Jasper \& Polletta, 2001), and often as factors which accelerate and intensify social movements (Van Stekelenburg \& Klandermans, 2007). It has been articulated that anger and guilt are the emotions most likely motivators of action, as opposed to shame, despair, or fear (for an overview, see Van Stekelenburg \& Klandermans, 2013, p. 893).

Gould's (2009) Bourdieusian work argues that it is the emotional habitus within an AIDS coalition movement which, in moving from shame to anger to despair, is responsible for the movement's development and eventual breakup. Woods et al. (2012) propose a 'ladder of emotions' that are foregrounded as movements proceed, drawing on their qualitative work with the campaigns of rural communities in England to show how emotions contributed to change. These works and more (for example, see the discussion of Adair [2005] below) show that the importance of understanding the emotions of protestors and social movement participants cannot be overestimated. Yet this article seeks to draw attention to the principle communicating the emotion of researchers as a methodological necessity, not as an indicator of movement behaviours amongst participants. It is believed that the incorporation of Bourdieusian reflexivity as the rationale for such a necessity is an original contribution, as may be the significance of seeing Mailer as a role model for such an approach, especially as we approach the fiftieth anniversary of the conflict in Vietnam.

\section{The Road to ‘68}

1968 is often considered the most tumultuous year of the second half of the twentieth century. The assassinations of Martin Luther King in April and Robert F. Kennedy in June (coming a mere five years after that of President John F. Kennedy) had savaged the mood of an already frayed nation. After King's death, rioting erupted across American cities as Black citizens struggled to maintain King's commitment to non-violent protest, a moment which for some indicated the death of 1960s liberalism (Risen, 2009). With the diversification of life brought about in part by the social changes of the 1960s, a nation with domestic strife found little sanctity abroad.

By 1968 the war in Vietnam had been active under various guises for 13 years, with the US government moving from supporting the South Vietnamese through military 'advisors' under Eisenhower, to a consignment of 16,000 personnel under Kennedy. After Kennedy's assassination in November 1963, and his election in November 1964, President Lyndon Johnson escalated 
American involvement in the conflict from a defensive position of protecting and advising the South Vietnamese to an offensive strategy aimed at wiping out the northern Vietcong. By December 1965 184,000 US military personnel were stationed in Vietnam, which increased threefold over the next three years (American War Library, 2008); at its peak in 1968, over 540,000 American troops were serving in Vietnam (DoVA, 2011).

With the US operating a policy of conscription since 1947, these troops included a large number of draftees. As a leading anti-war activist and founder of Students for a Democratic Society (SDS), one of the groups which organised the protests in Chicago, Tom Hayden said of the draft as an incitement to rebel and fight the state:

The first thing you learned in the Civil Rights movement was that fear was the enemy, and overcoming fear was the very purpose of the struggle...That carried over into the protests against the Vietnam war. And the draft had a way of focusing the mind of a young person. It was not just that you were fighting for an abstract cause, you were fighting for something all too real, something that thousands of your fellow citizens were dying senselessly for.

Hayden, in O’Hagan, 2008

While the sheer numbers of young men either being drafted or volunteering to serve made the Vietnam War a continuing and terrible reality for the US public, it was also the first conflict to be understood through television, making it a nightly spectacle. The power of images to elicit emotions was evident throughout the war, particularly the world famous, and Pulitzer Prize winning, photograph of a naked nine year-old Vietnamese girl running down a road after being burned in a napalm attack (see Faas \& Fulton, 2000). In later consideration, Richard Nixon would claim that it was the fact that Vietnam occurred through camera lenses and in the public's front rooms that contributed to the idea that America were 'fighting in military and moral quicksand' rather than any operation or aims of the war itself (Nixon, in Hallin, 1986, p. 3). Perhaps the most important media intervention was when CBS Evening News anchor Walter Cronkite, the 'most trusted man in America' according to one 1972 poll (Winfrey \& Schaffer, 2009), decried the Vietnam War as unwinnable, asserting that America was in stalemate, and that 'the only rational way out' would be a negotiated settlement (Hallin, 1986, p. 170).

It would be churlish and inaccurate to say that Norman Mailer's coverage of two nonmainstream protests against the Vietnam War was considered part of the turning of public opinion against the war. But the military, social, and political crises that America experienced in the late-1960s were to provide the established print media an opportunity to challenge the increasingly investigative and literal news reporting seen on television, an explicit aim of Mailer's (Lourve, 1988, p. 76). As the lifestyle magazines and colour supplements of newspapers sought a greater role in American public life, Mailer formed part of a vanguard movement which sought to shift literary and journalistic horizons.

\section{Norman Mailer and the New Journalism}

The novelist has lost her/his naivety: no longer does the writer work, within the purity of a formalized tradition, but within the disruptions of the volatile velocity of the space age.

Fair, 1988, p. 62

Norman Kingsley Mailer was born in New Jersey in 1923 and lived many lives before his death in November 2007. Not content with authoring two dozen fiction and nonfiction 
books, he was an actor, film director, essayist and reporter, playwright, and political candidate, standing unsuccessfully to be Mayor of New York in 1969. After a relatively normal middle-class upbringing, Mailer went to Harvard at age of 16 to study aeronautical engineering. He served in the Philippines in World War II, using his experiences as inspiration behind his most critically successful fiction work, The Naked and the Dead, which in 1948 launched him into the literary world.

By all accounts a complex and difficult character with a dangerous penchant for alcohol and violence, Mailer was a leading figure in American literature and wider society for six decades. Admired for his voracious appetite for work (H. Mills, 1985) and disdained for his ego (Rolling Stone magazine name checked him as part of the 'most pretentious moments in history' [Taibbi, 2012]), Mailer's legacy is perhaps rather unfulfilled. As someone who saw himself as the greatest American writer of his generation, and, it can be argued, whose fiction career never quite again reached the critical peak of his initial work (H. Mills, 1985, p. 20), Mailer's ego can be seen as bruised and bloodied, but never bowed, in his autobiographical reporting in Armies and Miami and Chicago. But this autobiographical style was not merely Mailer's own, rather part of a much larger reaction toward literature in the 1960s and 1970s.

Norman Mailer's name, alongside those of Tom Wolfe, Hunter S. Thompson, George Plimpton, Truman Capote and others, are remembered as key players in a literary movement called New Journalism. As the journalist Frank Rich said in the introduction to Miami and Chicago, the 'American tumult of the 1960s required a new language to chronicle it' (Rich, 2008 , p. viii). Towards such an end, the commandments behind New Journalism were codified as '[a]ctivist, advocacy, participatory, tell-it-as-you-see-it, sensitivity, investigative, saturation, humanistic, reformist and a few more' (MacDougal, 1971, p. v), a subjective and normative approach to exploring social events. Mailer himself came inadvertently to the movement earlier than most, writing 'Superman Comes to the Supermarket' (1960), an essay about an interview with John F. Kennedy for Esquire magazine before the Presidential election of 1960, which would later form the basis of a collection of works, The Presidential Papers (Mailer, 1963/1976). 'Superman' would contain much of the dramatic flair of Mailer's later protest reporting, mixing his own personal opinions and experiences alongside his political investigations, utilising the imagery and metaphor of the novelist. For example, this was Mailer's take on Robert Kennedy in 'Superman':

Bobby Kennedy, the archetype Bobby Kennedy, looked like a West Point cadet, or, better, one of those reconstructed Irishmen from Kirkland House one always used to have to face in the line in Harvard house football games. "Hello," you would say to the ones who looked like him as you lined up for the scrimmage after the kickoff, and his type would nod and look away, one rock glint of recognition your due for living across the hall from one another all through Freshman year, and then bang, as the ball was passed back, you'd get a bony king-hell knee in the crotch. He was the kind of man never to put on the gloves with if you wanted to do some social boxing, because after two minutes it would be a war, and ego-bastards last long in a war.

Mailer, 1960

Mailer perceptively noted that JFK brought the cult of personality and celebrity to American politics, and would later reflect on the vital role Jackie Kennedy played in US culture (Mailer, 1963/1976, p. 95-112). The challenge that this threw down to established political journalism, both the access that could be gained through Mailer's own celebrity status and the resources that 
could be offered by writing for America's 'lifestyle' magazines, demonstrated that 'Superman' had cemented the possibility of a new kind of journalism, 'filled with egotism, opinions, irreverence, and irrelevancies' (Harry Ransom Center, 2007). Wolfe (1973) later further codified New Journalism in a collection of essay extracts from authors whom he felt had participated in the movement, living up to a manifesto which encouraged writers to witness events first hand, think of their participants as characters in a novel, and bring events to life through extended use of dialogue. This was in order to steer away from the 'matter of fact' approach to reporting deeply emotional events (Yilmaz, 2005, p. 251), which was seen in American political and social journalism in the 1960s (Rich, 2008). Instead, attempts to 'tell the truth' became 'more self-conscious and the uncertainty of the dividing line between fiction and non-fiction was foregrounded rather than obscured' (Taylor, 2003, p. 18).

This section has served to briefly illustrate to the reader Norman Mailer's background and his role in the changing nature of American journalism in the 1960s, alongside the political context against which he wrote Armies and Miami and Chicago. The next section will expand upon the methodological and theoretical context for this article, that of the sociology of Pierre Bourdieu and his call for reflexive sociology. The focus will then move to a close reading of the texts to demonstrate the clear overlap between this call and the autobiographical reportage of Mailer in Washington and Chicago, and how these can provide social researchers with guidance and inspiration to produce work which is far more literary and closer to the lived experience of data collection.

\section{Bourdieu: Negating Subjectivity through Reflexivity}

Bourdieu's sociological investigations utilised advanced quantitative and qualitative techniques (Hamel, 1998), with no obvious pattern or rhythm established in his chosen approaches. His early studies of Algeria (Bourdieu, 1979) used ethnographic research and some statistical evidence, such as those exploring Arab marriage practices, and used photography (see Bourdieu, 2012) to develop his sociological eye as he trained himself as a fieldworker:

He tried out a range of techniques: surveys, observations, in-depth interviews, sketches of village geography and houses, and even Rorschach tests

$$
\text { Calhoun, 2012, p. ix }
$$

In Distinction (1979/2010) the (qualitative) cultural tastes of respondents were (quantitatively) mapped in order to produce a hierarchy of cultural capital and awareness. In Homo Academicus (1988), Bourdieu draws on a biographic narrative of his own journey into the elite of higher education and French society, alongside the statistical evidence drawn from a study of higher education. This serves to advance his work highlighting the reproductive and reinforcing nature of education; rather than its promise to act as an instrument of social mobility, the originating habitus and social profile of students remains more determinant to outcomes than their academic capital (Bourdieu, 1988, 1989; Bourdieu \& Passeron, 1977). Yet despite this earlier methodological variance, later in his career Bourdieu concentrated his research processes around one methodological pillar: the need for reflexivity (Bourdieu, 2003; Bourdieu, 1999), most thoroughly documented in An Invitation to Reflexive Sociology (Bourdieu \& Wacquant, 1992; see also Bourdieu, 1990).

There were three main facets to Bourdieusian reflexive sociology, spelt out by Schirato \& Webb (2003). These required, firstly, a focus on the disciplinary and academic situ, the 'scholastic 
point of view' or the intellectual bias and dispositions required by an academic field (Kenway \& McLeod, 2004, p. 528-9); the second, an analysis of the researcher's own position within the academic field; and thirdly, and most importantly for this article, the social origins of the researcher. It is this third strand, the focus on researcher positionality, which shall be examined now, and shall form the basis of this critique of Mailer's work. ${ }^{3}$

As Bourdieu (2003, p. 287) wrote:

Nothing is more false, in my view, than the maxim almost universally accepted in the social sciences according to which the researcher must put nothing of himself into the research.

He argued that researchers must be reflexively aware of their own habitus, such as their own predispositions, knowledges and competences while undertaking research, in order to produce, if not objective, then honest and open research. Bourdieu drew on examples from his studies in Algeria and his home village of Béarn to demonstrate how 'idiosyncratic personal experiences methodically subjected to sociological control constitute irreplaceable analytic resources, and that mobilizing one's social past through self-socio-analysis can and does produce epistemic as well as existential benefits' (Bourdieu, 2003, p. 281).

Famously, Bourdieu's first lecture on entering the Collège de France was the 'Lecture on the Lecture' (Bourdieu, 1990, p. 177-98), where he deconstructed the issues he faced in giving such as esteemed public performance, in front of an audience of the most acclaimed academics in French society. In his final lecture of this series, entitled 'Sketch for a self-analysis', he subjected himself to the exercise of autobiographical reflexivity for which he had been a proponent. Republished as the book of the same name, it is his effort to codify his feelings on his own habitus and resultantly explain his work's trajectory. The first half of the book is academically situated, continuing Bourdieu's assertion that the contextual detail required for sociologists to produce sociology is the academic construct in which they find themselves: he later, for example, termed Homo Academicus a 'very self-conscious "epistemological experiment"' (Bourdieu \& Wacquant, 1992, p. 67). He aims, against authors such as Sartre who Bourdieu dismisses with quiet anger as someone too comfortable in the established academic elite, and who refused to 'call the intellectual world into question' in the same way that intellectuals called the world into question (Bourdieu, 2007, p. 23), to create a 'sociologistic interpretation of the sociological description of the intellectual world' (Bourdieu, 2007, p. 25) - the sociology of sociology. This involves clarity about moving beyond the narcissistic researcher merely writing about themselves, to that of 'participant objectification' (Bourdieu, 2003), concerned with explaining the conditions in which the research intervention takes place.

In The Weight of the World, Bourdieu (1999, p. 608) explores and explains the social relationship which exists in all research, quantitative or qualitative, which renders impossible the 'positivist dream of an epistemological state of perfect innocence'. He instead posits that a certain amount of compromise is required in defining the possibilities of social research. It is not possible to achieve an omniscient and objective insight into the behaviours and attitudes of social actors, but we must remember that the social researcher finds himself or herself better placed than most to study and comprehend the world around them. This point is well-made in Homo

3 For more on Bourdieu's examination of the 'scholastic point of view' see Bourdieu (2000) and Kenway \& McLeod (2004). It may be that as multidisciplinary journals grow in size and influence this examination of differing scholastic approaches, and differing ontological and epistemological doctrines increases, and may even see the need for separate disciplinary dispositions diminish. 
Academicus (1988, p. 31), where Bourdieu writes that:

Marx suggested that, every now and then, some individuals managed to liberate themselves so completely from the positions assigned to them in social space that they could comprehend that social space as a whole, and transmit their vision to those who were still prisoners of the structure. In fact, the sociologist can affirm that the representation which he produces through his study transcends ordinary visions, without thereby laying claim to such absolute vision, able fully to grasp historical reality as such. Taken from an angle which is neither the partial and partisan viewpoint of agents engaged in the game, nor the absolute viewpoint of a divine spectator, the scientific vision represents the most systematic totalization which can be accomplished, in a given state of the instruments of knowledge, at the cost of as complete as possible an objectification both of the historical moment and of the work of totalization.

Social researchers can only do so much, but they are well positioned to do what they do. Accusations of subjectivity in social research are used to undermine its argument, its validity and accuracy, to posit that findings are not 'true'. Yet Bourdieu is arguing that for a researcher to pretend they are an objective outsider, unaffected by their habitus and the experience of data collection, is a double untruth, misleading both about oneself and ones' findings. Being aware of one's objectivities, and making them clear to the reader, is, he argues, preferable to pretending they do not exist. Mailer's Armies and Miami and Chicago are examples of this approach when applied to social protest.

It is the central argument of this article that through this open, and some may say confessional, approach to research and writing, we can produce academic research which is far closer to the lived experiences of our research participants. It will be shown that Mailer's awareness of his subjectivity, and his continuing self-exploration of how his relationships, biography, emotions and experiences before, during and after the protests affect his judgement, aids our understanding of these protests. What could be labelled a deficit of Mailer's research, the honest admittance of the lack of objectivity, is beneficial and perhaps the only way to overcome accusations of subjectivity.

\section{'History as a Novel...'}

In Armies, Mailer's reportage of the 1967 protest begins inauspiciously. The book starts with an extract from Time magazine, detailing Mailer's drunken and rambling performance at a pre-march peace rally at a Washington D.C. theatre. After the extract focusing on his lewd remarks and belligerent attitude, Mailer makes the rather pointed remark, 'Now we may leave Time in order to find out what happened' (Mailer, 1968, p. 14). Mailer is setting his stall out early, remarking that a politicised media, who he feels did not report either the confrontation at the theatre nor the march on the Pentagon properly or accurately, are biased reporters in favour of the conservative, pro-war establishment. His argument is instead that his voice, a voice which produces a narrative aware of his own foibles, is the most suitable and proper voice to explain to the reader 'what happened'. He is more than aware his voice has the texture of 'a Swiss cheese' (Mailer, 1968, p.14), damaged by drink and drugs, but Mailer understands that he is a deeply subjective person and dominated by these substances and subjectivities. However, this demonstrates the willingness to subject his own behaviour to similar analysis to which he subjects other actors in his narrative. Conversely, in Miami and Chicago Mailer has less of a need to explain or give reason for his autobiographical approach to reporting, as Armies had already 
been well-received and rewarded.

Armies proceeds to tell the story of the march on the Pentagon, the days leading up to it which included the night at the theatre and other events around Washington D.C., including a draft card burning. Later, the book concentrates on the days following the march, where Mailer was held in prison and went before a judge, seeking bail following his arrest for breaking a police line and trying to enter the Pentagon. The whole story is told through the third person, with Mailer referring to himself as 'Mailer' throughout (in Miami and Chicago he refers to himself as 'the reporter'). Mailer realises that if the narrative were to focus on Jerry Rubin, Dave Dellinger, or other leaders of the anti-war movement the history of the event would be fatally flawed. Yet equally, a protagonist who had no connection to the events would leave the reader blind. Instead '.. an eyewitness who is a participant but not a vested partisan is required, further he must not only be involved, but ambiguous in his own proportions' (Mailer, 1968, p. 64). It could be argued that Mailer here is demonstrating the most incredible egotism, arriving at the conclusion that it is he, coincidentally, who is best placed to report these events. He meets this charge head on, stating the narrator should be '.... an egotist of the most startling disproportion, outrageously and often unhappily self-assertive' (Mailer, 1968, p.65) in order to access opportunities and to stimulate events around him. This would be tied to the self-reflexivity of the novelist who was '... in command of a detachment... (and so in need of studying every last lineament of the fine, the noble, the frantic, and the foolish in others and himself)' (Mailer, 1968, p. 65).

In Miami and Chicago Mailer's reporting has a less clear narrative and spatial structure, moving from the nominating convention centre to the Chicago parks where the protests and running battles with the police occur. ${ }^{4} \mathrm{He}$ witnesses some of the battles with the police, but has to rely on the reporting of others to understand exactly what happens in others. The book is more fragmented as he tries to document the political machinations occurring across Chicago, concerning who will be chosen as the Democratic Party's nominee in the wake of Johnson pulling out of the race, and who would be selected as their running mate. However he still uses the same literary devices as in Armies and analyses the events around him through the novelists' gaze. Mailer remarks upon the literary import of symbols, how they are vital for protest because they inspire common cause. Without Lyndon Johnson to oppose, the protest in Chicago was fractured and disjointed (with some of the protestors such as the Yippies longing for such a disjointed mess). Mailer highlights these differences between the events in Armies and Chicago, and the consequence of lacking a symbol of oppression in the latter:

...symbol had the power to push him into actions more heroic than himself. The fact that he had been marching to demonstrate against a building which was the living symbol of everything he most despised - the military-industrial complex of the land - had worked to fortify his steps. The symbol of the Pentagon had been a chalice to hold his fear; in such circumstances his fear had even flavoured his courage with the sweetest emotions of battle. But in Chicago there was no symbol for him.

Mailer, 1968/2008, p. 144

Mailer had seen his personal symbols of American positivity and possibility, JFK and RFK, taken away, and he now used the negative symbol of Johnson as a way to centre his discontent. He reports his emotive cry as he learned of Bobby Kennedy's assassination (Mailer, 1968/2008, p. 93), and the deep convictions he holds about Democratic politics, exemplified by his mistrust of the supporters of Gene McCarthy, is in stark comparison to his open confusion at the Republican

4 A series of striking videos from these confrontations can be seen at http://www.youtube.com/watch?v=avje9r4m6E4 
convention in Miami, where he freely admits to neither understanding their machinations nor their politics (Mailer, 1968/2008, p. 92-3). These themes, the emotional and oftentimes ignorant reporter or researcher are further instances of Mailer opening himself up, showing his weaknesses, and explaining to the reader exactly where he is coming from: his politics, emotions, biography, and preferences are made clear to the reader.

On the centrality of emotion, Jasper (1998, p. 421) writes that most emotions 'far from subverting our goal attainment, help us define our goals and motivate action toward them'. Mailer's emotions, and those along whom he was protesting, were key to his actions, just as they were in corollary for Adair (2005) in her study of what she learned as a result of her participation in the anti-globalisation protests at the 'battle of Seattle' in 1999. Adair attended as part of a welfare-recipients advocacy group, consisting mostly of women and ethnic minorities, many of whom had their children with them. Yet rather than being included in the main demonstrations of organised labour such as the steelworkers, Adair's group were side-lined, insulted through sexist and classist language, and even sexually assaulted. Adair's emotional academic reaction to this bullying was to look at the relationship between the traditional working-class and the povertyclass in the US. Her emotional response to the stigmatisation of her gender and income level at this protest openly affected her academic output, and as with Mailer's work the communication and methodological rigour is improved, not lessened, as a result.

In Armies Mailer is also ready and willing to open up about his instrumental reasons for participating in certain elements of the narrative. For example, Mailer is aware that his arrest at the Pentagon offers an excellent source of access to protestors, marshalls, and the police, and as such is an opportunity for data collection. When in prison he furthers this, treating his own experiences journalistically, seeing the offer of breakfast in jail as a chance to 'see a new locale' (Mailer, 1968, p. 202) rather than as a chance to eat. He is honest and open about his own preconceptions about how events at the march would progress, assuming that he would be treated like the other prisoners. 'Next to his vanity was a disproportionate modesty - he had actually believed he would be arrested and released with no particular attention paid to him' (Mailer, 1968, p. 219).

Throughout his reportage, Mailer's method is to provide passionate and literary opinions about events ('the Democratic Party had here broken in two before the eyes of a nation like Melville's whale charging right out of the sea' [Mailer, 1968/2008, p. 172]), significant people ('McCarthy looked weary beyond belief, his skin a used-up yellow, his tall body serving for no more than to keep his head above the crowd at a cocktail party' [Mailer, 1968/2008, p. 95]), and America's current state ('Every day the average American drove himself further into schizophrenia...American needed the war' [Mailer, 1968,p. 200-1]). However he also provides a largely dispassionate analysis of himself, an analysis which is central to Bourdieu's reflexive project. This analysis demonstrates his awareness that he is not an objective reporter; that does not make his analysis wrong, but instead layers it with deeper meaning.

\section{'...the Novel as History'}

Battles are peak experiences. They represent a distillation of the environmental forces (both social and natural) that lead to them, and they provide an essential reality by which the observer of social phenomena might judge the causes of such phenomena.

Akatiff, 1974, p. 26

Mailer understands the embodied subjectivities of ethnographic research, noting that 
'Revolutionaries for the weekend should never get hangovers' (Mailer, 1968, p. 67), understanding that these biological and physiological emotions mess with the experience and interpretation of events. His psychological condition also comes under scrutiny, with constant questioning of his own position within the literary oeuvre, seen in his jealousy of Robert Lowell, the American poet who upstages Mailer at the pre-march rally (Mailer, 1968, p. 55-6), his invitations to other famous authors to join the march on the Pentagon, and his worry over the quality of his recent work, asking 'His career, his legend, his idea of himself - were they stale?' and describing his own activity as 'getting a little soft, a hint curdled' (Mailer, 1968, p. 69). This paranoia, made central in Armies, causes Mailer to obsess about the reception his arrest is making in the outside world, confident that the newspapers, purveyors of, he feels, twenty years of misreporting, would label him an aggressive agitator (Mailer, 1968, p. 152). This paranoia is commonplace in social research, but, as Shane Blackman (2007) has argued, stems from the researcher being afraid of revealing too much about themselves, aware of opening up emotionally and finding themselves subject to criticism.

Yet this obfuscation creates problems for the salience and accuracy of data. Mailer's emotional welfare comes into play in Armies as he recounts the conversation he has with his wife, the one phone call he is allowed from jail. In it she recounts what his two sons had done that day, and how his four daughters from previous marriages would be visiting that weekend (Mailer, 1968, p. 177-81). This quiet reflection, on the quality of his parenting and tenderness of his marriage adds little to the explanation of the protest, but serves to provide autobiographical data, giving us a more precise understanding of the lens through which Mailer is interpreting events. This methodological necessity is further served, in a deeply political book about a deeply political event, by a passage where Mailer explains his political positions to the reader and their position within the wider context of American military strategy and international relations (Mailer, 1968, p. 196-201). These contrasting but complimentary approaches signify that Mailer knows that if he is to be successful in using an autobiographical approach to report on a significant national event, the reader has the right to be fully aware of that biography.

Yilmaz (2005), in an attempt to analyse Mailer's autobiographical style, argues that Mailer uses his own experience of the protests as a lens through which to view them because he sees them as emblematic of the wider protest against the Vietnam war. Further, methodologically he recounts how Mailer saw events which were both public and deeply internal and intimate, and so uses the instinct of the novelist to recapture the precise feeling of the ambiguity of the events (Mailer, 1968), and therefore uses himself as the 'means toward illuminating the events he is describing' (Merrill, in Yilmaz, 2005, p. 253). As a result Holloway sees Armies as 'an explicit attack on the objectivity and impersonality of the conventional media' (Holloway, in Yilmaz, 2005, p. 253). Protests are emotional events where many conflicting thoughts and practices can combine in a maelstrom of anger and anguish (Woods et al., 2012). To try and write a narrative that aims to include the diverse range of opinions, worries, judgements of a large crowd of protestors, would often produce a practically impossible and unsatisfactory job. In trying to explain all the events, the researcher would explain none.

Mailer's autobiographical and reflexive style overcomes this. By framing the events through just one lens - his own - we are told one version of events, one account of the overriding emotions and stories of the day. And yet, in order to counteract accusations of bias and subjectivity, Mailer employs the reflexive approach to make the reader fully and disarmingly aware of those subjectivities. By opening himself up, we get to see the full emotional gamut of one participant, a focus on depth rather than breadth. 


\section{Discussion: Protests as Biography}

Tom Wolfe said of Mailer's writing within the canon of New Journalism that Armies was his best work, with Miami and Chicago and A Fire on the Moon (1970), Mailer's detailed exploration of the Apollo 11 mission, substandard in terms of New Journalism's remit:

Because there was, in fact, no celebrity there in that march in Armies of the Night who was of any greater magnitude than he was. This put him at the center of the action, as so it worked. It did not work in Of a Fire on the Moon [sic].

Wolfe, in Bellamy, 1990, p. 66

Wolfe criticised Miami and Chicago because in his view Mailer had not encountered events which any standard news reporter could not have encountered. While it is true that Miami and Chicago relies more heavily on reportage, particularly that from The Village Voice (see Mailer, 1968/2008, p. 170-2), to say that Mailer has the standard protest and riot experiences is a disingenuous oversight. Mailer's arrest and interactions with the police, his failed attempts to organise a separate march through Chicago, and how his novelist's gaze falls upon central politicians, are a few of the many ways in which Mailer's account goes above and beyond regular news reporting. 'Mailer cannot play the role of the detached and omniscient author, any more than he can or will imitate the newspaper men, whose daily duty is to mask the self' (Stone, 1982, p. 280).

But Wolfe is right to identify the problem with the autobiographical approach, where the detail required for the wider contextual setting of events cannot be studied in person. The autobiographical method suffers when the content is not based on personal experience: 'Mailer always does better when he is forced to deal with new, real material' (Wolfe, in Levine, 1990, p. 168). Mailer understood this. He knew that if he wanted recognition as both a novelist covering a protest and as a protestor documenting a protest in a novel, he had to express both his own experiences and his understanding of the march's origins and purposes. Therefore, Armies concludes with Mailer's history of the organisation and delivery of the march on the Pentagon, seeing it as part of a wider social construction, as part of a battle of ideas (Mailer, 1968, p. 231300). Mailer saw this section as the part of the novel which can be put to use, a technical document based on interviews, official documents, and media reports; after the subjective exploration of data collection during the march, the data is framed and contextualised by secondary analysis and an absence of the personal. By completing these two projects, he felt the collective whole was so much more:

Then he began his history of the [march on the] Pentagon. It insisted on becoming a history of himself over four days, and therefore was history in the costume of a novel... Yet in writing his personal history of these four days, he was delivered a discovery of what the March on the Pentagon had finally meant, and what had been won, and what had been lost, and so found himself ready at last to write a most concise Short History...no, rather as some Novel of History, to elucidate the mysterious character of that quintessentially American event.

Mailer, 1968, p. 228

Mailer makes two central claims about the need for this approach in Armies: that intimacy with the narrator counters bias in the content, and that we must relegate 'factual' history and news 
reporting behind the novelistic approach because the very structure of history is too accepting of the US's military industrial complex. In parallel with Bourdieu's recognition that the established academy fails to understand the importance of the 'scholastic point of view', Mailer comments on the crooked instruments of science and writing (including his own), 'constructed in small or large error' (Mailer, 1968, p. 231), that we continue to trust in only because of our familiarity with those who built them. In reaction to this assertion, and as a comment on the nature of reflexivity, Lourve (1988, p. 73) argues that Mailer manages to both challenge the primacy of historians and reporters and the novelist as sufficient reporters of events. In being willing to question his own legitimacy, Mailer communicates a rarely-spoken truism about the nature of research.

To construct and write social science reflexively is not to abandon the rigour of academic and scientific inquiry, to ignore the issues of sampling, bias and exaggeration. Instead it can be a cure for these problems, to address these issues honestly and thoroughly, to 'foreground rather than obscure' (Taylor, 2003, p. 18) the line between fact and (personal) fictions. There is no argument for reflexive work to dominate a piece of research, for it is important to remember that researchers are not the sole experiencers of events, but the reporters, cataloguers, and communicators of such events. As a final conclusion, it is in the communication of this work that we can perhaps learn the most from thinking of Norman Mailer as a social researcher.

\section{Conclusion: A Literary Future for the Social Sciences?}

C. Wright Mills in The Sociological Imagination (1959, p. 217) finds himself aghast at the quality of writing within the social sciences, wearied and worried at the prevailing 'turgid and polysyllabic prose', not for intellectual reasons but for emotional and personal ones. Most academics, he contends, are fearful of being judged and dismissed by their peers as mere journalists, who believe that to be readable is to be superficial. This is, he feels, a systemic problem of superiority, perpetuated through generations of academics in social science faculties across the world (pre-empting Bourdieu's [1988] own work on the academic field), rather than a belief in egalitarianism where everyone should have the benefit of being educated or of having access to the social research.

Human beings speak and write with all their experiences, all their faults, all their positives, and all their drawbacks. Their presentation may not be polished, but it will be accurate, of reality, and honest. The Mailer revealed in Armies and Miami and Chicago is dishevelled, at times drunken, forthright, self-confident, and fearful. Mills witnessed a growth in machinelike presentation of sociology, and states that to dehumanise the presentation of sociology is 'pretentiously impersonal' (C. W. Mills, 1959, p. 221). Those that understand research produced in such a way will be inward looking, and those who do not understand will be alienated. As Mills continued, '[a]ny writing...that is not imaginable as human speech is bad writing' (C. W. Mills, 1959, p. 221). ${ }^{5}$ Academics have a great responsibility to be a representative of a grand linguistic tradition and are expected to 'try and carry on the discourse of civilized man' (C. W. Mills, 1959, p. 222). As Les Back (2007, p. 164) has argued:

Mills was also clear that sociological imagination meant being self-consciously committed to affecting argument and writing creatively for a variety of what he called 'reading publics'. The danger he foresaw was that the sociological work might develop a technical language that turns inward on itself...To avoid this we have to aspire to make sociology more literary.

5 Ironically, Bourdieu fails on this point, as discussed by Jenkins (1992, p. 9). 
By utilising writers such as Mailer, who produce rather unedited, holistic, and confessional reflexive essays on real social events we may not be any closer to addressing concerns over subjectivity in qualitative research, but we may get closer to understanding social protests as biographical phenomena in an individual, who chooses to communicate their findings in an accessible, democratic, and engaging manner. Rich (2008, p. viii) remarks on how Mailer felt the reports of the New York Times on a racial confrontation in Miami were devoid of feeling and emotion, lacking any sense of the meaning of the event, a critique accurate of the coverage of the London riots of 2011. As social scientists seeking Weberian 'verstehen' (see Tucker, 1965), with a desire to uncover the meaning of protests for individuals and groups, rather than merely information about them, we must be able to see some parallels and some inspiration in Mailer's work.

\section{References}

Adair, V. C. (2005). US working-class/poverty-class divides. Sociology, 39, 5, 817-834.

Akatiff, C. (1974). The March on the Pentagon. Annals of the Association of American Geographers, 64, 1, 26-33.

American War Library (2008). Vietnam War Allied Troop Levels 1960-73. Retrieved March 22nd 2013 from http://www.americanwarlibrary.com/ vietnam/vwatl.htm

Back, L. (2007). The Art of Listening. London, UK: Berg.

Bellamy, J. D. (1990). Sitting Up with Tom Wolfe. In D. Scura (Ed), Conversations with Tom Wolfe (pp. 56-72). Jackson, MS: University Press of Mississippi.

Blackman, S. (2007). Hidden Ethnography: Crossing Emotional Boundaries in Qualitative Accounts of Young People's Lives. Sociology 41, 4, 699-716.

Bourdieu, P. (1979/2010). Distinction: A Social Critique of the Judgement of Taste. London: Routledge.

Bourdieu, P. (1988). Homo Academicus. Stanford, CA: Stanford University Press.

Bourdieu, P. (1989). The State Nobility. Stanford, CA: Stanford University Press.

Bourdieu, P. (1990). In Other Words: Essays towards a reflexive sociology. Cambridge, UK: Polity.

Bourdieu, P. (1999). The Weight of the World. Cambridge, UK: Polity.

Bourdieu, P. (2000). Pascalian Meditations. Cambridge, UK: Polity.

Bourdieu, P. (2003). Participant Objectivation. Journal of the Royal Anthropological Institute, 9, 281-94.

Bourdieu, P. (2007). Sketch for a Self-analysis. Cambridge,
UK: Polity.

Bourdieu, P. (2012). Picturing Algeria. New York, NY: Columbia University Press.

Bourdieu, P., \& Passeron, J. C. (1977). Reproduction in Education, Society and Culture. London, UK: Sage.

Bourdieu, P., \& Wacquant, L. (1992). An Invitation to Reflexive Sociology. Cambridge, UK: Polity.

Calhoun, C. (2012). Foreword In P. Bourdieu. Picturing Algeria (pp. vii-xvi). New York, NY: Columbia University Press.

DoVA (2011). Military bealth pocket Card for Clinicians. Department for Veterans Affairs. Retrieved March 24th 2013 from http://www.va.gov/oaa/ pocketcard/vietnam.asp

Faas, H., \& Fulton, M. (2000). The Survivor: Phan Thi Kim Phuc and the photographer Nick Ut. The Digital Journalist. Retrieved March 20th 2013 from http://digitaljournalist.org/issue0008/ submenu_coverstory.htm

Fair, A. (1988). The Beast in the Jungle: Mailer, Eastlake and the Narrating of Vietnam. In A. Lourve and J. Walsh (Eds) Tell Me Lies about Vietnam (pp. 62-72). Milton Keynes, UK: Open University Press.

Goodwin, J., Jasper, J., \& Polletta, F. (2001). Passionate Politics: Emotions and Social Movements. Chicago, IL: University of Chicago Press.

Gould, D. (2009). Moving Politics: Emotion and ACT UP's Fight against AIDS. Chicago, IL: University of Chicago Press.

Hallin, D. (1986). The 'Uncensored War': The Media and Vietnam. London, UK: University of California Press.

Hamel, J. (1998). The positions of Pierre Bourdieu and Alain Touraine respecting qualitative 
methods. British Journal of Sociology, 49, 1, 1-19.

Harry Ransom Center (2007). Norman Mailer. Retrieved March 21st 2013 from http:/ /www. hrc.utexas.edu/press/releases/2007/mailer

Jasper, J. (1998). The emotions of protest: Affective and reactive emotions in and around social movements. Sociological Forum, 13, 3, 397-424.

Jenkins, R. (1992). Pierre Bourdieu. London, UK: Routledge.

Kahn, S. (2011). Privilege: The Making of an Adolescent Elite at St. Paul's School. Oxford, UK: Princeton University Press.

Kenway, J., \& McLeod, J. (2004). Bourdieu's reflexive sociology and 'spaces of points of view': whose reflexivity, which perspective? British Journal of Sociology of Education, 25, 4, 525-44.

Levine, M. (1990). An Interview with Tom Wolfe. In D. Scura (Ed), Conversations with Tom Wolfe (pp. 167-71). Jackson, MS: University Press of Mississippi.

Lourve, A. (1988). The Reluctant Historians: Mailer and Sontag as Culture Critics. In A. Lourve and J. Walsh (Eds) Tell Me Lies about Vietnam (pp. 73-87). Milton Keynes, UK: Open University Press.

MacDougal, C. D. (1971). Interpretive Reporting, Sixth Edition. New York, NY: MacMillan.

Mailer, N. (1960). Superman Comes to the Supermarket. Esquire. Retrieved March 21st 2013 from http://www.esquire.com/features/supermansupermarket

Mailer, N. (1963/1976). The Presidential Papers. St Albans, UK: Granada.

Mailer, N. (1968). The Armies of the Night. London, UK: Penguin.

Mailer, N. (1968/2008). Miami and the Seige of Chicago. New York, NY: NYRB Classics.

Mailer, N. (1970). A Fire on the Moon. London, UK: Pan Books.

McAdams, D. P. (2008). Personal Narrative and the Life Story. In O. John, R. Robins \& L. A. Pervin (Eds), Handbook of Personality: Theory and Research, Third Edition (pp. 242-62). New York, NY: Guildford Press.

Mills, C. W. (1959). The Sociological Imagination. New York, NY: Oxford University Press.

Mills, H. (1985). Mailer: A Biography. Sevenoaks, UK: New English Library.

O'Hagan, S. (2008). Everyone to the Barricades. The Guardian. Retrieved March 20th 2013 from http://www.guardian.co.uk/world/2008/ jan/20/1968theyearofrevolt.features

Polletta, F. (2008). Storytelling in politics. Contexts, $7,4,26-31$.

Polletta, F. (2009). Storytelling in Social Movements .In H. Johnston (Ed.), Culture, Social Movements and Protest (pp. 33-54). Farnham, UK: Ashgate.

Rich, F. (2008). Introduction In N. Mailer (Ed.), Miami and the Seige of Chicago (pp. vii-xi). New York, NY: NYRB Classics.

Risen, C. (2009). A Nation on Fire: America in the Wake of the King Assassination. Hoboken, NJ: John Wiley \& Sons.

Schirato, T., \& Webb, J. (2003). Bourdieu's concept of reflexivity as metaliteracy. Cultural Studies, 17 , 3/4, 539-52.

Sikes, P., \& Gale, K. (2006). Narrative Approaches to Education Research. Retrieved March 23rd 2013 from http://www.edu.plymouth.ac.uk/ resined/narrative/narrativehome.htm

Stone, A. (1982). Autobiographical Occasions and Original Acts: Versions of American Identity from Henry Adams to Nate Shaw. Philadelphia, PA: University of Pennsylvania Press.

Taibbi, M. (2012). The 10 most pretentious moments in history: Readers speak out. Rolling Stone. Retrieved March 20th 2013 from http://www.rollingstone. com/politics/blogs/taibblog/the-10-mostpretentious-moments-in-history-readersspeak-out-20121226

Taylor, M. (2003). The Vietnam War in History, Literature andFilm. Edinburgh, UK: Edinburgh University Press.

Tucker, W. T. (1965). Max Weber's Verstehen. The Sociological Quarterly, 6, 2, 157-65.

Van Stekelenburg, J., \& Klandermans, B. (2007). Individuals in movements: A social psychology of contention. In: C. M. Roggeband and B. Klandermans (Eds) The Handbook of Social Movements across Disciplines (pp. 157-204). New York, NY: Springer.

Van Stekelenburg, J., \& Klandermans, B. (2013). The social psychology of protest. Current Sociology, 61, 7, 886-905.

Van Zoonen, L. (2005). Entertaining the Citizen: When politics and Popular Culture Converge. Oxford, UK: Rowman \& Littlefield.

Winfrey, L., \& Schaffer, M. D. (2009). Walter Cronkite dies. The Philadelphia Inquirer. Retrieved March 20th 2013 from http://articles.philly.com/200907-17/news/24985744_1_walter-cronkiteunited-press-wire-service-marlene-adler

Wolfe, T. (1973). The New Journalism. London, UK: 
Pan Macmillan.

Woods, M., Anderson, J., Guilbert, S., \& Watkin, S. (2012). 'The country(side) is angry': Emotion and explanation in protest mobilization. Social \& Cultural Geography, 13, 6, 567-85.

Yilmaz, K. (2005). Norman Mailer's March: Autobiographical Concerns in Norman Mailer's The Armies of the Night. Journal of Faculty of Letters, 22, 1, 249-58. 